\title{
THE EFFECT OF BRAIN GYM ON DEPRESSION LEVELS IN ELDERLY, NOGOSARI DISTRICT, BOYOLALI, CENTRAL JAVA
}

\author{
Rita Untari
}

School of Health Polytechnic, Surakarta

\begin{abstract}
Background: Elderly interpreted as a period of decline in physical and psychological functioning. This will have a negative effect on stressful situation and result in depression. This depressive state has an impact on the implementation of daily activities. One cognitive therapy method that can be applied to treat depressive disorders is to do a brain gym. Brain gym strives to activate the left and right brain optimally with simple movements and accompanied by music. This study aimed to determine the effect of the brain gym on depression levels in the elderly.

Subjects and Method: This was an experimental one group pre-test and post-test design conducted at Tegalgiri Village, Nogosari, Boyolali, Central Java, from October to November, 2017. A total sample of 27 elderlies was selected by quota sampling. The dependent variable was depression. The independent variables (intervention) were brain gym with eight times and each session lasting 10-15 minutes. The data were collected by Geriatric Depression Scale (GDS) version 15. The depression score uses a numerical scale. The data were analyzed by pairwise comparison test.

Result: Depression before intervention (Mean= 7.96) after the intervention (Mean=6.45). The results of the comparison test obtained $(\mathrm{r}=0.89$; $95 \% \mathrm{CI}=1.23$ to $1.74 ; \mathrm{t}=11,98, \mathrm{p}<0.001, \mathrm{df}=$ 26).

Conclusion: There are different levels of depression before and after the intervention. Brain gym has an influence on the level of depression in the elderly in Tegalgiri Village, Nogosari Boyolali. Encourage local health cadres to further activate integrated healthcare center for the elderly, one of the activities is gymnastics, including a brain gym.
\end{abstract}

Keywords: Elderly, Brain Gym, Depression

\section{Correspondence:}

Rita Untari. School of Health Polytechnic, Surakarta, Jl. Letjen Soetoyo Mojosongo, Surakarta. Email: ritauntari@gmail.com. Mobile: 08164278544

The $7^{\text {th }}$ International Conference on Public Health Solo, Indonesia, November 18-19, 2020 | 387 https://doi.org/10.26911/the7thicph.05.19 